УДК 681.324(06)

doi: $10.26906 /$ SUNZ.2018.1.028

С.О. Оберемок

Кіровоградська льотна академія

Національного авіаційного університету, Кропивницький

\title{
МОДЕЛЬ ОБРОБКИ ПАКЕТІВ В КОМУТАЦІЙНИХ ВУЗЛАХ З ПОВНОЗВ'ЯЗНОЮ ТОПОЛОГІЮЮ МЕРЕЖІ АСУ ПОВІТРЯНИМ РУХОМ
}

\begin{abstract}
В роботі розглянуті принциии побудови системи передачі даних в автоматизованих системах управління повітряним рухом, щзо створена в Україні та функціонує в рамках міжнародної системи обміну інформацією про повітряний рух. Проведений аналіз дозволив стверджувати, що існуюча система побудована за ісрархічним принципом передачі та обробки інформачії. Для передавання інформаиії використовуються приничии комутаиії буферизованих пакетів із застосуванням різних стратегій, які можуть впливати на основні характеристики проиесу комутаиії пакетів в мережі АСУ повітряним рухом. В результаті досліджень було встановлено, щзо для розробки комутаційних засобів в мережах необхідно використовувати буферну пам'ять яка розрахована на максимальне інформаиійне навантаження.
\end{abstract}

Ключові слова: комутація, буфер, вхіднй порт, вихідний порт, передача даних, буферна пам'ять, мультиплексор, бітова швидкість.

\section{Вступ}

В даний час обмін даними радіолокаційної інформації (РЛІ) в автоматизованих системах управління повітряним рухом (АСУ ПР) ведеться, в основному, по виділених каналах зв'язку.

У той же час в країнах СС для цієї мети останнім часом застосовуються ієрархічні мережі з обробкою пакетів в комутаційних вузлах, які, перш за все, дозволяють скоротити експлуатаційні витрати i зробити систему обміну РЛІ легко масштабованою і розширеною.

Постановка задачі і аналіз відомих публікацій. Однією 3 поширених технологій комутації $\epsilon$ організація даного процесу у засобах 3 повнозв'язно топологією. Аналіз видань [1-4, 6] показав що у комутаторах 3 повнозв'язною топологією між будь якими портами (вхідними, вихідними) існує єдиний шлях. У мережах передачі даних АСУ повітряним рухом імовірність виникнення довготривалих пікових навантажень дуже значна.

Виходячи 3 цього актуальним $є$ завдання проведення досліджень можливості комутації пакетів без втрат в найкоротший термін.

Мета статті. Моделювання принципів обробки пакетів в комутаційних вузлах 3 повнозв'язною топологією в мережах АСУ повітряним простором.

\section{Основна частина}

В результаті розвитку мережевої технології 3'явилася концепція комутації на вузлах 3 повнозв'язною топологією. У вузлах мережі розміщують сервери, здатні забезпечити можливість багатьом терміналам й ЕОМ спільно використовувати загальну комутаційну лінію, що має велику пропускну здатність. Сучасні засоби комутації, як правило розраховані на середнє інформаційне навантаження.

У комутаторах 3 повнозвя'зною топологією між будь-яким вхідним і вихідним портом існує єдиний шлях (рис. 1)

Пакети які поступають на вхідні порти передаються на адресні фільтри (АФ) всіх вихідних портів. Якщо вказаний в пакеті адреса збігається з номером вихідного порту, що надійшов пакет поміщається у вихідний буфер (Б), звідки, згодом, відправляється одержувачу через блок мультиплексорів (БМ) [5].

У класичному варіанті число буферів кожного вихідного порту дорівнює кількості вхідних портів. Слід також зазначити, що в загальному випадку граничні швидкості передачі даних через порти можуть бути різні i, як правило, визначаються протоколами обміну.

При цьому однією з вагомих завдань процесу комутації залишається передача буферізованих пакетів у вихідний порт, яка може вирішуватися із застосуванням різних стратегій (наприклад, випадкова вибірка, послідовний опитування, пріоритетне обслуговування та ін.), Що в кінцевому рахунку впливає на основні характеристики процесу комутації пакетів.

У мережах передачі даних АСУ повітряним простором ймовірність виникнення довготривалих пікових навантажень дуже значна. Зважаючи на це актуальною є задача аналізу можливості комутації пакетів без втрат в найкоротші терміни.

Розглянемо процес комутації з $\mathrm{N}$ вхідних портів на один вихідний порт, який схематично представлено на рис. 2. 


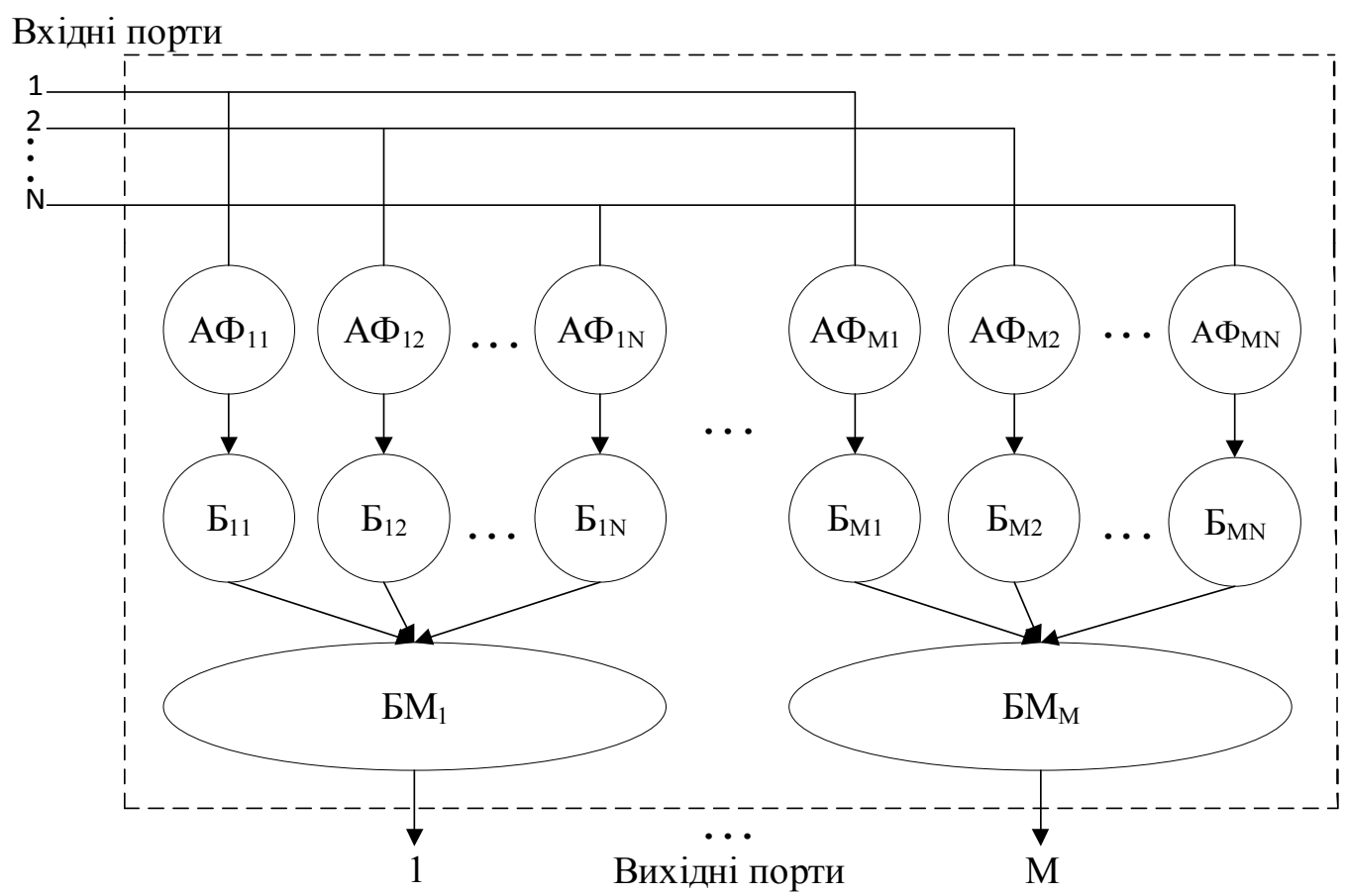

Рис. 1. Узагальнена структура комутатора з повнозв'язною топологією

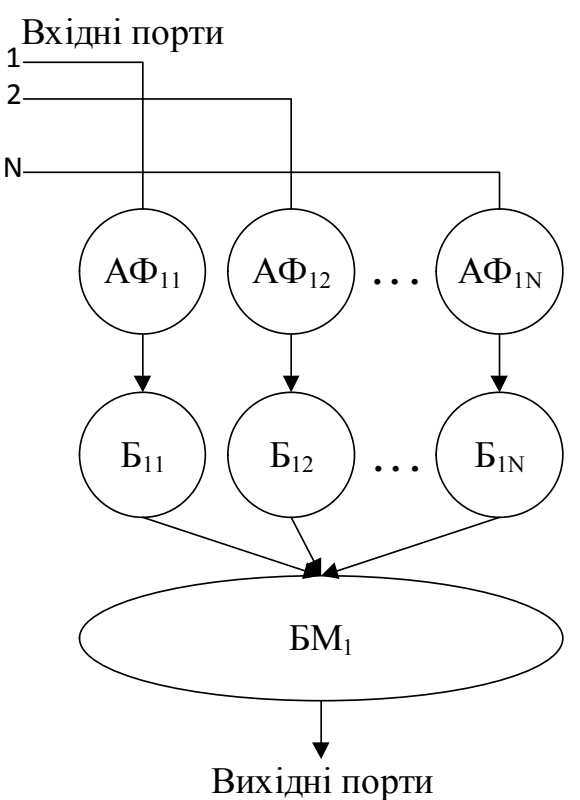

Рис. 2. Схема комутації пакетів з $\mathrm{N}$ вхідних на один вихідний порт

Позначимо через $\mathrm{B}_{\mathrm{i}}^{\mathrm{BX}}$ бітові швидкості роботи вхідних портів; через $\mathrm{B}^{\text {вых }}$ - бітову швидкість вихідного порту. Приймемо довжини буферів однаковими для кожного з комутованих шляхів:

$$
\mathrm{BUF}_{1}=\mathrm{BUF}_{2}=\ldots=\mathrm{BUF}_{\mathrm{N}}=\mathrm{BUF} .
$$

У критичних умовах, коли на кожен вхідний порт комутатора пакети надходять з максимальною інтенсивністю, здатність передавати дані без втрат буде залежати від довжини буферів і бітових швид- костей вхідних і вихідних портів. У загальному випадку, час до першої втрати пакета комутатором при однакових бітових швидкостях вхідних портів може бути приблизно оцінений як:

$$
\widehat{\mathrm{T}}_{\text {пот }} \approx \frac{\mathrm{N} \cdot \mathrm{BUF}}{\mathrm{N} \cdot \mathrm{B}^{\mathrm{BX}}-\mathrm{B}^{\mathrm{BHX}}} .
$$

Бачимо, що для випадку, коли бітова швидкість вихідного порту перевищує сумарну бітову швидкість всіх вхідних портів ймовірність втрати пакетів комутатором буде дорівнює нулю. В такому випадку розміри буферів можуть бути мінімальними лише для здійснення проміжного зберігання даних, що передаються [7-8].

Виходячи 3 наведеного виразу можна також отримати орієнтований розмір буферів, який забезпечить буферизацію вхідних пакетів без втрат для заданого часу пікового навантаження.

В процесі моделювання досліджувалися комутатори з наступними характеристиками:

a) кількість вхідних портів комутатора $\mathrm{N}=16$, бітові швидкості вхідних портів $\mathrm{B}_{\mathrm{Bx}}=10$ Мбіт / c, бітова швидкість вихідного порту $\mathrm{B}_{\text {вих }}=100$ Мбіт / с (графік залежності 1, рис. 3.);

б) $\mathrm{N}=32, \mathrm{~B}_{\mathrm{Bx}}=10$ Мбіт / с, $\mathrm{B}_{\text {вих }}=100$ Мбіт / $\mathrm{c}$ (графік залежності 2, рис. 3);

в) $\mathrm{N}=8, \mathrm{~B}_{\mathrm{Bx}}=10$ Мбіт / c, $\mathrm{B}_{\text {вих }}=10$ Мбіт / c (графік залежності 3, рис. 3);

г) $\mathrm{N}=64, \mathrm{~B}_{\mathrm{Bx}}=10$ Мбіт / с, $\mathrm{B}_{\text {вих }}=10$ Мбіт / с (графік залежності 4, рис. 3);

д) $\mathrm{N}=8, \mathrm{~B}_{\text {вх }}=100$ Мбіт / с, $\mathrm{B}_{\text {вих }}=10$ Мбіт / с (графік залежності 5, рис. 3). 


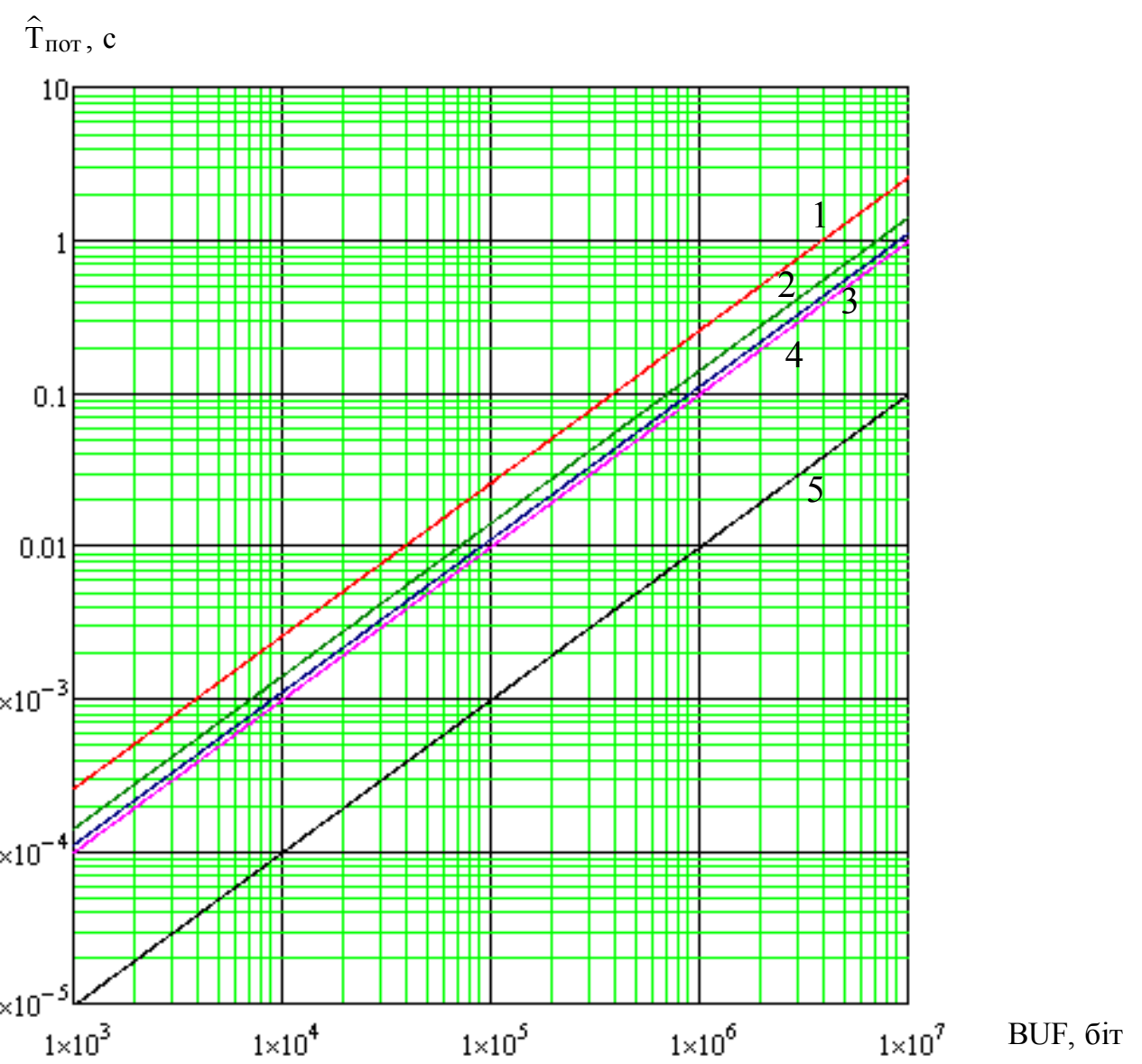

Рис. 3 Залежність оцінки часу втрати пакета комутатором від довжини буферів при однакових бітових швидкостях вхідних портів при комутації пакетів на один вихідний порт:

$$
\begin{aligned}
& 1-\mathrm{B}_{\text {вх }}=10 \text { Мбіт / с, } \mathrm{B}_{\text {вих }}=100 \text { Мбіт / с; } \\
& 2-\mathrm{N}=32, \mathrm{~B}_{\text {вх }}=10 \text { Мбіт / с, } \mathrm{B}_{\text {вих }}=100 \text { Мбіт / c; } \\
& 3-\mathrm{N}=8, \mathrm{~B}_{\text {вх }}=10 \text { Мбіт / c, } \mathrm{B}_{\text {вих }}=10 \text { Мбіт / c; } \\
& 4-\mathrm{N}=64, \mathrm{~B}_{\mathrm{BX}}=10 \text { Мбіт / с, } \mathrm{B}_{\text {вих }}=10 \text { Мбіт / c; } \\
& 5-\mathrm{N}=8, \mathrm{~B}_{\text {вх }}=100 \text { Мбіт / c, } \mathrm{B}_{\text {вих }}=10 \text { Мбіт / с }
\end{aligned}
$$

Попередні оцінки часу до втрати пакетів для ріЗакінчення табл. 1 зних параметрів наведені в табл. 1.

Таблиця 1

Розрахункова оцінка часу до втрати пакетів

\begin{tabular}{|c|c|c|c|c|}
\hline $\begin{array}{c}\text { ВUF, } \\
\text { Мбит }\end{array}$ & $\mathrm{N}$ & $\mathrm{B}^{\mathrm{BX}}$, бит/с & $\mathrm{B}^{\text {вых }, \text { бит/с }}$ & $\hat{\mathrm{T}}_{\text {пот }}, \mathrm{c}$ \\
\hline \multirow{4}{*}{1} & 16 & 10 & 100 & 0,267 \\
\cline { 2 - 5 } & 32 & 10 & 100 & 0,145 \\
\cline { 2 - 5 } & 8 & 10 & 10 & 0,114 \\
\cline { 2 - 5 } & 64 & 10 & 10 & 0,102 \\
\cline { 2 - 5 } & 8 & 100 & 10 & 0,01 \\
\hline \multirow{3}{*}{10} & 16 & 10 & 100 & 2,667 \\
\cline { 2 - 5 } & 32 & 10 & 100 & 1,455 \\
\cline { 2 - 5 } & 8 & 10 & 10 & 1,143 \\
\hline
\end{tabular}

\begin{tabular}{|c|c|c|c|c|}
\hline \multirow{1}{*}{} & 64 & 10 & 10 & 1,016 \\
\cline { 2 - 5 } & 8 & 100 & 10 & 0,101 \\
\hline \multirow{3}{*}{100} & 16 & 10 & 100 & 26,667 \\
\cline { 2 - 5 } & 32 & 10 & 100 & 14,545 \\
\cline { 2 - 5 } & 8 & 10 & 10 & 11,429 \\
\cline { 2 - 5 } & 64 & 10 & 10 & 10,159 \\
\cline { 2 - 5 } & 8 & 100 & 10 & 1,013 \\
\hline
\end{tabular}

Виходячи 3 даних табл. 1 розробимо модель процесу комутації.

В якості вихідних обмежень приймемо наступні:

- комутатор працює в режимі пікового завантаження (максимальна інтенсивність надходження пакетів на всі вхідні порти); 
- застосовується стратегія випадкового вибору пакетів $з$ проміжних буферів для мультиплексування на вхідний порт;

- передаються кадри мінімального розміру (найгірше поєднання параметрів трафіку) [9].

Як випливає 3 отриманих результатів моделювання (рис. 3), при однакових розмірах буферів найбільший час до втрати пакетів забезпечить найменш "завантажений" комутатор.

Причому, більш істотний вплив на час до першої втрати пакетів надають вхідні і вихідні бітові швидкості.

Збільшення кількості вхідних портів збільшує завантаження комутатора і зменшує час до першої втрати пакетів.

\section{Висновки}

В результаті досліджень стало зрозуміло що для розробки комутаційних засобів в мережах автоматизованих системах управління повітряним рухом необхідно використовувати буферну пам'ять яка розрахована на максимальне інформаційне навантаження. Використовувати такий підхід 3 погляду можливості апаратної реалізації відносно вимог є не ефективним.

Виходячи $з$ цього можна вважати що перспективним напрямком є розробка підходів до управління потоками даних в рамках комутаційного вузла мережі автоматизованої системи управління повітряним рухом, з метою забезпечення високої імовірності доставки даних в умовах пікового завантаження на комунікаційних вузлах.

\section{Список літератури}

1. Алиев Р. Т. Методы управления трафиком в мультисервисных сетях / Р. Т. Алиев // Информачионные технологии и системыл. - 2011. - №1. - C. 10-13.

2. Бертсекас Д. Сети передачи данных / Д. Бертсекас, Р. Галлагер / пер. с англ. - М.: Мир, 2009. - 544 c.

3. Дымарский Я. С. Проблемы оптимизации распределения ресурсов в сетях связи / Я. С. Дымарский // Телекоммуникации. - 2010. - № 3. - С. 12-17.

4. Кучерявый Е. А. Управление трафиком и качество обслуживания в сети Интернет / Е. А. Кучерявый. - М.: Наука и Техника, 2014. - 336 с.

5. Пасечников И. И. Геометризация пространств состояния каналов связи и путевых потоков информационныхх сетей // Радиотехника. - 2003. - №5. - C. 91-95.

6. Автоматизированные систем управлени воздушны движением: Новые информационные технологи 6 авиащии: Учеб. пособие. По ред. Пятк С.Г. и Красов А.И. СПб.: Политехника, 2010.

7. Lee G. M. A survey of multipath routing for traffic engineering // Proc. of LNCS 3391. Springer-Verlag. - 2015. Vol. 4. - P. 635-661.

8. Tahilramani K. H., Weiss A., Kanwar S., KalyaNaraman S., Gandhi. A. BANANAS: An evolutionary framework for explicit and multipath routing in the internet // Proc. ACM SIGCOMM Workshop on Future Directions in Network Architecture. Karlsruhe. - 2013. - P. 277-288.

9. EUROCONTROL Standard document for radar data exchange. Part 2 a Transmission of monoradar data target reports. SUR.ET1.ST05.2000-STD 02a-01. Edition 1.1,2012.

Надійшла до редколегії 4.12.2017

Рецензент: д-р техн. наук, доц. М.А. Павленко, Харківський національний університет Повітряних Сил імені І.вана Кожедуба, Харків.

\title{
МОДЕЛЬ ОБРАБОТКИ ПАКЕТОВ \\ В КОММУТАЦИОННЫХ УЗЛАХ С ПОЛНОСВЯЗНОЙ ТОПОЛОГИЕЙ СЕТИ АСУ ВОЗДУШНЫМ ДВИЖЕНИЕМ
}

\author{
С.О. Оберемок
}

В работе рассмотрены принципы построения системы передачи данных в автоматизированных системах управления воздушным движением, созданная в Украине и функционирует в рамках международной системы обмена информацией о воздушном движении. Проведенный анализ позволил утверждать, что существующая система построена по иерархическому принципу передачи и обработки информации. Для передачи информации используются принципы коммутации буферизуемых пакетов с применением различных стратегий, которые могут влиять на основные характеристики процесса коммутации пакетов в сети АСУ воздушным движением. В результате исследований было установлено, что для разработки коммутационных средств в сетях необходимо использовать буферную память, рассчитанную на максимальное информационную нагрузку.

Ключевые слова: коммутачия, буфер, входной порт, выходной порт, передача данных, буферная память, мультиплексор, битовая скорость.

\section{MODEL OF PROCESSING PACKAGES IN COMUTING HOLES WITH COMPLICATED TOPOLOGY OF ACS NETWORK WITH AIR DRYER}

\section{S.O. Oberemok}

The paper considers the principles of the construction of a data transmission system in automated air traffic control systems established in Ukraine and functions within the framework of the international system for the exchange of information on air traffic. The analysis made it possible to assert that the existing system is based on the hierarchical principle of transmission and processing of information. For information transfer, the principles of switching buffered packets using different strategies are used, which may affect the basic characteristics of the packet switching process in ACS network by air traffic. As a result of researches it was established that for the development of switching means in networks it is necessary to use buffer memory which is designed for the maximum information load.

Keywords: switching, buffer, input port, output port, data transfer, buffer memory, multiplexer, bit rate. 